\title{
DEVELOPING EFL STUDENTS' WRITING SKILL THROUGH SELF-ASSESSMENT INTEGRATED WITH E-PORTFOLIO
}

\author{
Moh. Taufik, Bambang Yudi Cahyono \\ Universitas Negeri Malang, Indonesia \\ (moh.taufik09.edu@gmail.com)
}

Received: $28^{\text {th }}$ August 2019; Revised: $27^{\text {th }}$ November 2019; Accepted: $28^{\text {th }}$ December 2019

\begin{abstract}
Writing is one of the language skills that should be mastered by students of English as a foreign language (EFL). In order to write well, EFL students should understand the content of their writing. They should also be able to discover some writing errors they may have. Therefore, it is necessary for the students to practice writing frequently and to be willing to review their writing products. This study aimed to develop EFL students' writing skill through self-assessment integrated with e-portfolio. It used action research design and it was conducted in a classroom consisting of 25 ten graders of Islamic Senior High School (Madrasah Aliyah Negeri) at Sumenep, East Java. The findings showed that the students' writing skill could be improved after the implementation of self-assessment integrated with e-portfolio. It is suggested that EFL teachers consider using self-assessment integrated with students' e-portfolio to help improve EFL students' writing skill.
\end{abstract}

Key Words: self-assessment; EFL students; e-portfolio; writing competence

\section{ABSTRAK}

Menulis merupakan kemampuan berbahasa yang harus dimiliki oleh pelajar bahasa Inggris sebagai bahasa asing (EFL). Dalam mengembangkan kemampuan menulis, pelajar dituntut untuk mengerti isi tulisan mereka dan mampu menemukan kesalahan-kesalahan yang mungkin terdapat dalam tulisan mereka. Maka dari itu, pelajar dipandang perlu untuk sesering mungkin melatih kemampuan menulis, mengulas kembali dan merevisi karya mereka. Penelitian ini bertujuan untuk mengembangkan kemampuan menulis siswa menggunakan self-assessment melalui elektronik portofolio. Penelitian ini merupakan Penelitian Tindakan Kelas (PTK) dengan subjek 25 siswa kelas X MAN Sumenep, Jawa Timur. Penemuan penelitian ini menunjukkan bahwa kemampuan menulis siswa membaik setelah penerapan self-assessment melalui elektorinik portofolio. Dengan demikian, guru bahasa Inggris disarankan untuk mempertimbangkan penerapan sefl-assessment melalui elektronik portfolio siswa untuk mengembangkan kemampuan menulis siswa.

Kata Kunci: self-assessment; pelajar bahasa Inggris; elektronik portofolio; kompetensi menulis

How to Cite: How to Cite: Taufik,M., Cahyono, B. Y. (2019). Developing EFL Students' Writing Skill Through SelfAssessment Integrated With E-Portfolio. IJEE (Indonesian Journal of English Education), 6(2), 171-186. doi:10.15408/ijee.v6i2.12019 


\section{INTRODUCTION}

One of the language skills that students of English as a foreign language (EFL) need to master is writing. In the teaching of EFL in Indonesia, students were required to learn receptive skills (listening and reading) and productive skills (speaking and writing). Thus, writing skill development is always present in English classrooms along with the other three skills. However, when writing is not chosen to be the skill to focus on in the lesson plan, English teachers may assign the students to practice writing through a journal to be submitted regularly, for example, it is written after the completion of a lesson or a unit of a textbook (e.g. Widiati, Rohmah \& Furaidah, 2014).

For some or many EFL students, writing skill might be very complex. Scrivener (2011) stated that writing requires learners to go through different kinds of mental process. They need more time to think, to reflect, to prepare, to rehearse, to make mistakes, and to find alternatives and better solution pertaining to what they write. The complexity of writing can also be seen from its use of language micro skills. Cunningsworth (1995) pointed out that at least there are three language micro skills involved in writing, namely paragraphing, spelling and punctuation. These micro skills are considered difficult to master in a relatively short period of time. From a preliminary study conducted in a classroom of a public Islamic Senior High School (Madrasah Aliyah Negeri) at Sumenep, East Java, it was found that most of the students have difficulties to use the correct grammatical forms and spelling. This can be seen from the students' class average score of their writing of narrative texts. This score was derived from a writing test conducted in the preliminary study. It was revealed that their average score on grammar and spelling was 69.16, which was lower than the required passing grade which is 75 .

To deal with the problem, it was suggested that the students practice writing more intensively and know their progress in the process of developing their ideas for writing. Allowing the students to know their progress in developing their writing enables them to grow their own awareness about the aspects of writing they need to improve. Hence, selfassessment is used in the present study. The implementation of self-assessment in language learning, especially writing, has been found to contribute positively towards writing development. Purwanti (2015) found that students showed positive attitudes towards the use of self-assessment in writing. They 
believed that using self-assessment let them identify mistakes they made when writing. Most of them were even encouraged to use self-assessment for future needs. Furthermore, the practice of self-assessment might be used to measure students' real English proficiency. Students who scored themselves low in self-assessment mostly scored low in English proficiency test. In the same line, those who scored high in self-assessment also scored high in English proficiency test. In other words, students' scores in selfassessment are reliable measures of their level of English proficiency (Mistar, 2011).

From the interview held with the English teacher during the prelimiminary study it was also known that self-assessment has been used in the teaching and learning process. However, the self-assessment was not used for the development of students' writing skill. Instead, self-assessment was used as a means of students' reflection upon what they have learned through a certain period of time. In this study, self-assessment was used as it has been found to increase students' direct involvement in learning, encouragement of autonomy, and leaning motivation (Purwanti, 2015). More particularly, the present study applied an alternative assessment in the form of e-portfolio as a means to develop the students' writing skill.

Implementing portfolio assessment encourages students to actively acquire language through classroom meeting with relatively limited time. In addition, it gives them more space to finish the assessment since they can continuously deal with their work in their leisure time outside school hours. A study conducted by Syafei (2012) found that the students has positive views on the implementation of portfolio assessment. One of the benefits of portfolio is that it provides more chances for the students to develop their writing skill independently. Students also stated that they had more possibility to explore their writing skill since they have more time available, longer than classroom hours. Furthermore, another benefit is that portfolio allows studehts to know the track of their development. At the end of a semester, they can compare the final score they get with the portfolio they have kept. In relation to this, Hammer (2007, cited in Syafei, 2012) stated that judging students' skill at one glance from a single test is risky. A single test does not give a complete picture of how students would perform if they were in a different situation.

One of the challenges in implementing portfolio assessment is to 
have the students work organized. Syafei (2012) found that some students were not happy to keep a portfolio because it was hard to keep their pieces of works together until the end of a semester. Furthermore, money consuming is worth concerning. Portfolio assessment requires students to write a single topic more than once, namely drafting and revising. A paperbased portfolio assessment is likely to burden students who have to prepare pieces of paper when they have to repeatedly revise their work (Syafei, 2012). To deal with this problem, the current study used e-portfolio. By relying on the use of electronic protfolio (e-portfolio), students do not need to prepare pieces of paper to keep a portfolio with them. Instead, they only need to submit and revise their work online using computer or mobile phone connected to the Internet. Ayan and Seferoğlu (2011) found that using eportfolio enabled students to be more organized. It allowed them to quickly notice which one is the first draft and its revisions. In addition, e-portfolio gives opportunities for them to see the progress of their writing more easily than the paper-based portfolio since they might open and check their work anywhere and anytime with their mobile tools. The students' e-portfolio was powered by Google Drive.
In accordance with the background, the present study was aimed to develop students' writing skill through self-assessment integrated with students' e-portfolio. The research questions are formulated as follows: 1) How can self-assessment integrated with e-portfolio develop students writing skill?; 2) How are students' opinions on the implementation of selfassessment integrated with e-portfolio?.

\section{METHOD}

The research design used in this study was collaborative action research. According to Burns (2010), action research is a one of research fields focusing on improving educational matters which involves educational participants, such as teachers, students, administrators, managers, and even parents. As it is aimed at educational improvement, action research always starts with problem identification to find a certain problem to solve. In this study the problem was identified during the preliminary study which revealed that the students had problems in writing. To solve the problem the first researcher acted as the teacher who applied the strategy, namely students' self-assessment integrated with e-portfolio. This study was collaborative action research as the 
English teacher of the school acted as an observer.

This study was carried out in state Islamic Senior High School (Madrasah Aliyah Negeri/MAN) at Sumenep, East Java, Indonesia. It involved ten graders of Science 1 (X MIPA 1) class consisting of 25 students: 5 male and 20 female students. When the study was conducted, the students were in the second semester of their three-year secondary education.

Kemmis and McTaggart (1988, cited in Burns, 2010) pointed out that action research consists of cycles. One cycle is proceeded and if it is successful to solve the problem, the cycle can be ended. However, if the first cycle has not succeeded in achieving the criteria of success, the next cycle should be conducted. There are four stages in one cycle of action research: planning, action, observation, and reflection. The four stages of this study are explained in the following part.

\section{Planning}

In the planning stage of this study, the lessons for the teaching of writing were planned. To achieve the objectives of the instruction, the teaching and learning activities were determined to be performed in four sessions (which are explained further in the action stage). In addition, in this stage, the criteria of success were specified. The present study was considered successful if it met three criteria: 1) the implementation of the strategy improves the students' achievement. More than $70 \%$ of the students attain scores at the minimum mastery level (75) or more; 2 ) the students are actively involved in the implementation of the strategy, and; 3) the students show positive opinion on the implementation of the strategy.

\section{Action}

In order to implement the strategy, which is students' self-assessment integrated with e-portfolio, the teaching and learning activities were held for four meetings as one cycle. Since in a week English is taught in one meeting, the present research was completed in four weeks. This study was implemented in six steps.

The first step was used to review and to develop students' knowledge of narrative text. The activities included group and class discussions. The learning approach was discovery learning which covered five stages, namely questioning, collecting data, associating, concluding, and communicating. The activities of this first step were conducted in all of the meetings. In the second step, which also happened in the first meeting, the students were introduced to the use of 
self-assessment and e-portfolio through lecturing and simulation. In the lecture, the students were informed on what to do in self-assessment, and in the simulation, the students were provided with a narrative text containing errors that were initially set. Then they were asked to examine the errors. After some errors were found, the students were guided to revise the text. The simulation was conducted twice to make sure that the students understand how to do self-assessment on their eportfolio.

The third step was to assign students to write a narrative text. After writing the text, students were asked to revise their writing and compare their writing with the criteria in the narrative self-assessment rubric so that they know the quality of their writing. The revision might be completed outside the school hours. The fourth step was to give feedback in the students' assignment in the areas they needed to improve. The students were also given a chance to ask questions or to inform their difficulties.

In the fifth step, the teacher answered the students' questions or provided students with assistance on their difficulties in working on selfassessment and e-portfolio. The fourth and the fifth steps were conducted from the first up to the fourth meeting. The last step of the study was scoring students' writing products. The students' progress in writing was examined by comparing one draft to another, from the first to the last draft. The summary of the teaching and learning activities in the six steps is shown in Table 1.

Table 1. The Steps of the Teaching and Learning Activities

\begin{tabular}{|c|c|c|c|c|c|c|}
\hline \multirow[t]{2}{*}{ Steps } & \multirow[t]{2}{*}{ Activities } & \multicolumn{4}{|c|}{$\begin{array}{l}\text { Classroom } \\
\text { Meetings }\end{array}$} & \multirow{2}{*}{$\begin{array}{l}\text { Outside } \\
\text { school } \\
\text { hours }\end{array}$} \\
\hline & & 1 & 2 & 3 & 4 & \\
\hline 1 & $\begin{array}{l}\text { Reviewing and } \\
\text { developing } \\
\text { students' } \\
\text { knowledge of } \\
\text { narrative texts }\end{array}$ & $\sqrt{ }$ & $\sqrt{ }$ & $\sqrt{ }$ & $\sqrt{ }$ & \\
\hline 2 & $\begin{array}{l}\text { Introducing self- } \\
\text { assessment and e- } \\
\text { portfolio through } \\
\text { lecturing and } \\
\text { simulation }\end{array}$ & $\sqrt{ }$ & & & & \\
\hline \multirow[t]{2}{*}{3} & $\begin{array}{l}\text { Assigning } \\
\text { students to write } \\
\text { a narrative text. }\end{array}$ & $\sqrt{ }$ & & & & \\
\hline & $\begin{array}{l}\text { Asking the } \\
\text { students to revise } \\
\text { the text focusing } \\
\text { on aspects which } \\
\text { need } \\
\text { improvement } \\
\text { outside the } \\
\text { classroom }\end{array}$ & & & & & $\sqrt{ }$ \\
\hline 4 & $\begin{array}{l}\text { Providing } \\
\text { feedback on } \\
\text { aspects that } \\
\text { students need to } \\
\text { improve and } \\
\text { giving them a } \\
\text { chance to ask } \\
\text { questions or } \\
\text { inform their } \\
\text { difficulties. }\end{array}$ & $\sqrt{ }$ & $\sqrt{ }$ & $\sqrt{ }$ & $\sqrt{ }$ & \\
\hline 5 & $\begin{array}{l}\text { Responding to } \\
\text { the students' } \\
\text { questions and } \\
\text { difficulties }\end{array}$ & $\sqrt{ }$ & $\sqrt{ }$ & $\sqrt{ }$ & $\sqrt{ }$ & \\
\hline
\end{tabular}




\begin{tabular}{|c|c|c|c|c|c|c|}
\hline \multirow[t]{2}{*}{ Steps } & \multirow[t]{2}{*}{ Activities } & \multicolumn{4}{|c|}{$\begin{array}{l}\text { Classroom } \\
\text { Meetings }\end{array}$} & \multirow{2}{*}{$\begin{array}{l}\text { Outside } \\
\text { school } \\
\text { hours }\end{array}$} \\
\hline & & 1 & 2 & 3 & 4 & \\
\hline 6 & $\begin{array}{l}\text { Scoring the } \\
\text { students drafts } \\
\text { in the students' e- } \\
\text { portfolio }\end{array}$ & & & & & $\sqrt{ }$ \\
\hline
\end{tabular}

\section{Observation}

Five instruments were used in this study. The first instrument was a narrative writing task. This instrument was used to know the students' writing skill before the implementation of the strategy and examine the progress of their writing achievement throuh multiple revisions in self-assessment. The rubric for scoring narrative text was adapted from Heilmann, Miller, and Dunaway (2010) and it consists of eight aspects: (1) introduction or orientation, (2) character development, (3) mental state, (4) referencing, (5) conflict and resolution, (6) cohesion, (7) grammar and spelling, and (8) conclusion. Each aspect is scored in five scales. (1) excellent (90-100), (2) good (80-89), (3) fairly good (70-79), (4) poor (60-69), and (5) extremely poor (50-59). The students' writing works were scored by the first researcher as the teacher in the study and the school teacher as the collaborator.The second instrument was self-assessment form to check the students' drafts. This instrument has eight aspects which are the same as the aspects uswd in the rubric for scoring narrative texts. Howeber, this instrument only has four scales with different values: excellent (4), good (3), fair (2), and poor (1). To help students decide which value choose, some descriptors were provided. The first and second instruments were used to achieve the first research criterion of success.

The third and the fourth instruments were field notes and observation sheets, respectively. They were used to know students' engagement and the researcher's performance during teaching and learning activities. In other words, these two instruments were used to make sure the achievement of the second criterion of success. The field notes were written by the researcher while observation sheet was completed by the collaborator.

The fifth instrument was questionnaire which was used to know students' opinion on the implementation of self-assessment integrated with e-portfolio. Thus, this instrument was used to reveal whether or not the students have positive opinion on the implementation of the strategy. There were 15 items included in the questionnaire which covered three major cmponents, namely (1) students' readiness towards online learning environment, (2) students' 
opinion about the implementation of self-assessment, and (3) students' opinion towards the implementation of e-portfolio. The questionnaire was disseminated to the students through their e-portfolio. There were four categories of answers that students had to choose to express their agreement with the statements: strongly agree (4), agree (3), disagree (2), and strongly disagree (1). The students are considered to have positive opinion on the implementation of the strategy if the average score of their responses fall into strongly agree or agree, while negative opinion is judged from their disagree and strongly disagree responses.

\section{Reflection}

This stage of the study aimed to reflect on the results of the umplementation of self-assessment integrated with e-portfolio based on the criteria of success. There are three criteria of success (1) improvement of the students' writing achievement, (2) active involvement of the students, and (3) the students' positive opinion on the implementation of self-assessment integrated with e-portfolio. These results are presented in more detail in the following section.

\section{RESULTS AND DISCUSSION}

\section{Results}

Improvement of the Students' Writing Achievement

The results of the analysis in the reflection stage show that after the implementation of self-assessment integrated with e-portfolio, the students' scores in their writing improved as shown in in Table 2.

Table 2. Students' average scores before and after the strategy implementation

\begin{tabular}{|c|c|c|}
\hline Phase & $\begin{array}{l}\text { Average } \\
\text { Score }\end{array}$ & $\begin{array}{l}\text { Number of } \\
\text { students } \\
\text { who scored } \\
\text { above } 75\end{array}$ \\
\hline $\begin{array}{l}\text { Before } \\
\text { implementation }\end{array}$ & 70.17 & $4(16 \%)$ \\
\hline First draft & 73.39 & $7(28 \%)$ \\
\hline Second draft & 75.06 & $13(52 \%)$ \\
\hline Third draft & 75.86 & $15(60 \%)$ \\
\hline $\begin{array}{l}\text { After } \\
\text { implementation } \\
\text { (The last draft) }\end{array}$ & 76.81 & $18(72 \%)$ \\
\hline
\end{tabular}

Table 2 shows that before the treatment was given, students' average score was 70.17. After the study was conducted, the students' average score was 76.81 (6.64 difference). Moreover, the number of students who could score more than or equal to 75 was more than $70 \%, 18$ students out of 25 students. Apart from the score comparison between before and after the study implementation, there was gradual improvement in the scores 
from the first to the last draft, from 73.39 , to $75.06,75.86$, and finally 76.81 .

To gain a further analysis of the draft-to-draft students' average score improvement, each aspect of narrative text being assessed was analyzed. It covered 8 different aspects which were (1) introduction, (2) Character development, (3) mental state, (4) referencing, (5) conflict and resolution, (6) cohesion, (7) grammar and spelling, and (8) conclusion. In general, the score of all aspects of narrative texts written by the students had reached 75 through the four drafts. The accumulative point of improvement showed that from the lowest to the highest was the cohesion aspect with 1.2 point, followed by the introduction and referencing aspects with 1.72 point, conflict and resolution aspects with 3.24 point, conclusion aspects with 3.32 point, mental state aspect with 3.6 point, character development aspect with 3.96 point, and grammar and spelling aspects with 8.56 point of improvement.

\section{Active Involvement of the Stdents}

The next success criterion of the present research was that there should be active involvement of the students in the learning and teaching activities through the steps covered in the strategy. There were five steps conducted in implementing selfassessment integrated with e-portfolio.
They were (1) checking students' background knowledge and developing students' comprehension on the narrative text; (2) introducing the idea of self-assessment and e-portfolio, and training students to use self-assessment integrated with e-portfolio; assigning students to write a narrative text on the e-portfolio and revise it based on the self-assessment; (4) giving administrative feedback and chance to share ideas or deliver questions concerning the students' progress in writing narrative text on the e-portfolio; and (5) responding to students' ideas and questions.

Through the five steps included in the strategy, the students were actively involved in learning activities. The first consideration was the fact that most of the students were actively involved in learning activities. Most students were actively involved in the group discussion and whole class discussion (in Step 1). The next consideration was that the students were able to complete the multiple revisions by relying on the provided self-assessment on the eportfolio (in Step 2).Then, the students were willing to share opinions and complaints towards the implementation of self-assessment integrated with eportfolio during feedback session and in the teaching and learning activities (in Step 3). Some students were complaining about the absence of 
sufficient tool to support their online assignment but this could be managed by asking other students to help their classmates (in Step 4). Finally, it is also suggested that the students review the learning material as a mean of confirming the quality of their writing (conducted by the teacher in Step 5).

\section{The Students' Opinion on Self-}

\section{Assessment Integrated with E- Portfolio}

The last success criterion was the presence of students' positive opinion on the implementation of selfassessment integrated with e-portfolio. The results of analysis of the15-item questionnaire showed that, in general, the students had positive opinions about the implementation of the strategy in terms of three aspects: the students' readiness on online learning (Items 1-6), their attitude towards the implementation of self-assessment (Items 7-10), and their attitude towards e-portfolio (Items 11-15).

In terms of the students' readiness on online learning, many of the students thought that it was not easy to get access to the Internet and to manage their study time effectively through online learning. They also felt the did not have enough understanding about technology to learn online. It is interesting to note that many of the students felt comfortable in composing text online and more than half of the students were motivated to learn online. Surprisingly, more than half of the students think that online learning was more motivating than the regular school sessions.

With regard to students' attitude towards the implementation of selfassessment, many of the students enjoyed doing self-assessment and they agreed that self-assessment let them understand what they had written. In addition, more than half of the students believed that self-assessment helped them develop their writing, These students also agreed to the implementation of self-assessment for the present and the future learning.

Finally, dealing with questions on the students' attitude to e-portfolio, most of the students liked the idea of eportfolio. However, many of them disagreed that e-portfolio let them learn better. More than half of the studets agreed that e-portfolio was likely to prevent them from making the same mistakes repeatedly. About half of the students thought that they planned to keep using e-portfolio. Most of the students, thought hat e-portfolio was better than paper-based portfolio. 


\section{Discussion}

Among the four macro skills of English, writing is considered the most complex skill. To develop a single text, students need to go through at least three stages, namely planning, reviewing, and revising, before the text is finalized (Weigle, 2007). The presence of self-assessment in this study helped students maximize the reviewing and revising stages. The self-assessment provided students with an indirect feedback on how the quality of their writing was expected to be. As a result, the students could improve their writing skill more independently. Another cause that resulted in improvement on the students writing skill was that, through the selfassessment, the students were encountered with several expectations more than once that they were assigned to revise their work for three times at least. It is in line with Ross et al, (1999, cited in Bing, 2016), stating that the more the students understand how they are expected to perform, the closer they are to the expectation. Finally, after several revisions, an improvement in students' writing quality was noticeable despite the fact that it was little, confirming the study conducted by Bing (2016) and Alfallay (2004).

More specifically on the narrative aspects, each student did not make an equal improvement even though through the final text revision, the students' score could reach 75 points. It confirmed the study conducted by Bing (2016) and Purwanti (2015). One of possible explanations was that the students' decision on which aspects they needed to revise was completely relied on their own judgment and language proficiency level; there was no teacher's feedback given (Lee \& Yoon, 2013).

The most significant improvement was in spelling and grammatical aspects. What took a significant impact on that improvement was, possibly, the students' previous learning experience (Li, 2018; Brown, Dewey \& Cox, 2014). The students had been surrounded by statement or explanation that grammar is one of the most complex English micro skills. Hence, what students concerned a lot when dealing with productive skills, namely writing and speaking, was grammar and spelling aspects.

Apart from self-assessment, the implementation of e-portfolio also helped the students improve their writing quality. The idea appeared when it was found that there were $28 \%$ students who could pass the passing grade in their first narrative draft, on which students had not been faced neither with self-assessment nor 
revision. This number was $12 \%$ higher than that in the preliminary study which was $16 \%$. The only possible explanation was that e-portfolio provides the students with more time to process the language compared to the one they had in regular in-class sessions. The burden on students to finish their writing as quickly as possible did not exist in e-portfolio. As result, they could use their language skill more effectively (Banfi, 2003; Syafei, 2012; Khodadady \& Khodabakhshzade, 2012).

The implementation of selfassessment integrated with e-portfolio was considered to have the students actively involved in learning activities, especially outside the classroom hours. It confirmed the study finding conducted by Mak and Wong (2017). The presence of the five steps in conducting the strategy was crucial to have the present study succeeded in reaching its objective. The first step which focused on reviewing and developing the students' comprehension on the text was confirmed by Scrivener (2011) to be the cause of an effective learning. Through reviewing, the students prepared themselves to gain further knowledge of the subject being discussed.

The next steps of the strategy were to introduce the idea of self-assessment and e-portfolio, to assign students to write a narrative text and revise it for at least three times based on the selfassessment, to give an administrative feedback and a chance to share ideas, and to respond to the students' idea. In general, these steps dealt with guiding students' progress in dealing with selfassessment and e-portfolio and were considered vital. It confirmed the study conducted by Khodadady and Khodabakhshzade (2012) especially for those who had not sufficiently experienced to encounter with selfassessment and to keep an e-portfolio. Furthermore, it is stated that selfassessment required the development of students' confidence in scoring themselves. According to Syafei (2012), it might take a relatively long period of time and require the presence of frequent feedback.

Rather than focusing the feedback on students' writing quality, the present study was determined to give the students administrative feedback alone. It was considered that focusing the feedback on administrative feedback rather than students' writing quality would prevent students from being dependent on teachers' direct feedback. Furthermore, metacognitive feedback provided through the self-assessment was considerably enough to help students develop their writing quality. 
It confirmed the study conducted by Mohammadi (2009).

Through the steps of the strategy, the students were also given the chance to share ideas or deliver questions concerning their progress on their assignment. Giving students a space to share idea was considered effective to develop students' learning autonomy as it is stated by Marzano, Marzano and Pickering (2003). Furthermore, the teacher's response towards the students' idea let the students feel noticed and more encouraged to be more actively involved in learning.

Over all, the students' opinion on the implementation of self-assessment and e-portfolio was positive, confirming the study conducted by Bing (2016), Butler and Lee (2010), Dann (2014), and Purwanti (2015). In terms of students' readiness towards online learning, which was covered in six statements in the questionnaire, the students were not likely ready. Even though they had enough understanding about technology, other elements of blended learning, such as the availability of online learning facility, time management, and students' dependency on English regular class where the teacher was present to guide them, were the causes of reluctance to do online assignment.
The students' opinion on on the self-assessment was positive. Some believed that self-assessment was enjoyable, let them understand better their writing, and improved their writing skill. Hence, some others stated that they wanted to implement selfassessment for their future needs. Unlike the self-assessment, a few students expressed negative perception towards e-portfolio. They were not sure that e-portfolio helped them learn better even though more of them believed that they had avoided making mistakes recorded on the e-portfolio. One possible reason was that, according to Syafei (2012), to develop students' skill to adjust themselves with portfolio assessment takes a relatively long period of time. Indeed, students who had no experience keeping portfolio might see its presence as a burden. Khodadady and Khodabakhshzade (2012) suggested that when implementing a portfolio assessment, students need to clearly understand what it is for and how it may contribute to their learning, and to be constantly guided.

The only aspect of e-portfolio to which students showed a higher positive opinion was its online-based assignment. They agreed that eportfolio was better than traditional portfolio, the paper-based portfolio. It confirmed a study conducted by Ayan 
and Seferoğlu (2011) that e-portfolio is more flexible than the paper-based portfolio. It opens possibility for students to evaluate their work wherever and whenever they wanted.

\section{CONCLUSIONS AND SUGGESTIONS}

The present study aimed to develop students' writing skill through self-assessment integrated with eportfolio. The results showed that there was an improvement on students' writing skill due to the implementation of the strategy. Apart from students' score improvement, this study succeeded to encourage students to be actively involved in learning and teaching activities which were conducted in five steps. Furthermore, many of the students had positive opinions on aspects related to online learning, self-assessment, and eportfolio. Most of the students enjoyed doing self-assessment and keeping eportfolio in spite of some difficulties faced during the completion of the assignment. In addition to it, some students were willing to remain doing self-assessment and keeping e-portfolio for their learning needs.

The implementation of selfassessment and e-portfolio encouraged learners to be aware of fairly independent learning. Teacher's motivational impulse on the students may have an important role in developing students' willingness in doing self-assessment and e-portfolio. This study was conducted in a relatively short period of time; therefore, it is suggested that the implementation of self-assessment integrated with e-portfolio take a longer time to achieve a significant development on students' writing skill. It als also suggested that future researchers investigate texts of various types to find out the effect of the implementation of self-assessment integrated with e-postfolio.

\section{REFERENCES}

AlFallay, I. (2004). The role of some selected psychological and personality traits of the rater in the accuracy of selfassessment and peer-assessment. System, 32, 407-425.

Ayan, D., \& Seferoğlu, G. (2011). Using electronic portfolio to promote reflective thinking in language teacher education. Educational Studies, 37(5), 513-521.

Banfi, C. S. (2003). Piloting portfolios: Using portfolios in pre-service teacher education. ELT Journal, 51(1), 34-42.

Bing, X. (2016). A study of the effects of students' self-assessment on the EFL writing of Chinese college students. Journalism and Mass Communication, $6(2)$, 91-107. DOI: 10.17265/21606579/2016.02.005

Brown, N. A., Dewey, D. P., \& Cox, T. L. (2014). Assessing the Validity of CanDo 
Statement in Retrospective (ThenNow) Self-Assessment. Foreign Language Annals, 47(2), 261-285.

Burns, A. (2010). Doing action research in English language teaching. New York: Routledge.

Butler, Y. G., \& Lee, J. (2010). The effects of self-assessment among young learners of English. Language Testing, 27(1), 5-31.

Cunningsworth, A. (1995). Choosing your coursebook. London: Macmillan Publisher.

Dann, R. (2014). Assessment as learning: Blurring the boundaries of assessment and learning for theory, policy and practice. Assessment in Education: Principles, Policy $\mathcal{E}$ Practice, 21(2), 149-166.

Heilmann, J., Miller, J. F., \& Dunaway, C. (2010). Properties of the narrative scoring scheme using narrative retells in young schoolaAge children. American Journal of Speech-Language Pathology, 10(19), 154-166.

Khodadady, E., \& Khodabakhshzade. (2012). The effect of portfolio and self-assessment on writing ability and autonomy. Journal of Language Teaching and Research, 3(3), 518 -524.

Lee, H. K. \& Yoon, E. (2013). Do Effects of Self-assessment Differ by L2 Language Level? A Case of Korean Learners of English. The Asian-Pacific Education Researcher (TAPER). DOI: 10.1007/s40299-013-0111-z.

Li, X. (2018). Self-Assessment as 'Assessment as Learning' in Translator and Interpreter Education: Validity and Washback. The Interpreter and Translator Trainer Journal, 2017(1), 1-20. DOI: 10.1080/1750399X.2017. 1418581.
Mak, P., \& Wong, K. M. (2017). SelfRegulation Through Portfolio Assessment in Writing Classrooms. ELT Journal. DOI: 10.1093/elt/ccx012.

Marzano, R. J., Marzano, J. S., \& Pickering, D. J. (2003). Classroom management that works; Research-based strategies for every teacher. Virginia: Association for Supervision and Curriculum Development.

Mistar, J. (2011). A study of the validity and reliability of self-assessment. TEFLIN Journal, 22(1), 45-58.

Mohammadi, M. (2009). Recast and metalinguistic feedback in teaching and learning L2 writing: A comparative study. The Journal of Asia TEFL, 6(3), 227-224.

Purwanti, T. T. (2015). The implementation of self-assessment in writing class: A case study at STBA Lia Jakarta. TEFLIN Journal, 26(1), 97-116.

Scrivener, J. (2011). Learning and teaching; The essential guide to English language teaching. London: Macmillan Publisher.

Kementrian Pendidikan dan Kebudayaan. (2016). Silabus Mata Pelajaran Sekolah Menengah Atas/Madrasah Aliyah/Sekolah Menengah Kejuruan/Madrasah Aliyah Kejuruan (SMA/MA/SMK/MAK). Jakarta: Kementrian Pendidikan dan Kebudayaan.

Syafei, M. (2012). Backwash effects of portfolio assessment in academic writing classes. TEFLIN Journal, 23(2), $206-221$. 
Tan, H. K. K., Teo, T. C., \& Shen, C. (2011). Variation in students' conceptions of self-assessment and standards. Education Research International, 2011(1), $\quad 1-9$. DOI:10.1155/2011/487130.

Weigle, S. C. (2007). Teaching writing teachers about assessment. Journal of Second Language Writing, 16(2017), 194-209.
Widiati, U., Rohmah, Z., \& Furaidah. (2014). Bahasa Inggris; SMA/MA/SMK Kelas X semester 1 [Englosh for 10 graders of Senior High Schools, Islamic Senior High Schools, and Vocational High Schools]. Jakarta: Pusat Kurikulum dan Perbukuan, Balitbang, Kemdikbud. 